\title{
エンジンファン着水における氷の離脱現象のモデル化
}

林 亮輔*1, 山本 誠 ${ }^{* 2}$

\section{Modelling of ice shedding phenomenon for engine fan icing}

\author{
Ryosuke HAYASHI ${ }^{* 1}$ and Makoto YAMAMOTO*2 \\ ${ }^{* 1}$ Graduate School of Mechanical Engineering, Tokyo University of Science \\ 6-3-1 Niijuku, Katsushika-ku, Tokyo 125-8585, Japan \\ ${ }^{* 2}$ Department of Mechanical Engineering, Tokyo University of Science \\ 6-3-1 Niijuku, Katsushika-ku, Tokyo 125-8585, Japan
}

\section{Received 2 April 2014}

\begin{abstract}
In a jet engine, icing phenomena may occur primarily on the fan blades, the fan exit guide vanes (FEGVs), the splitter, and the low-pressure compressor. Accreted ice disturbs the inlet flow and causes large energy losses. In addition, ice accreted on a fan rotor can be shed from the blade surface due to centrifugal force and can damage the compressor components. This phenomenon, which is typical in turbomachinery, is referred to as ice shedding. The ice shedding phenomenon is very complicated because there are several unknown physical properties of ice, such as the ice density, the adhesion force between accreted ice and the wall, and the contact force between ice pieces. Moreover, although existing icing models can simulate ice growth, these models do not have the capability to reproduce ice shedding. In the present study, we developed an icing model that takes into account both ice growth and ice shedding. We validated the proposed ice shedding model through the comparison of numerical results and experimental data, which includes the flow rate loss due to ice growth and the flow rate recovery due to ice shedding. The predictive shedding time obtained using the proposed ice shedding model were in good agreement with the experimental data. Finally, we investigated the effects of ice growth and ice shedding on the fan performance.
\end{abstract}

Key words : Ice accretion, Ice shedding, Multiphysics CFD, Jet engine, Axial fan

\section{1. 緒言}

航空機が運航する高度の雲の中には，過冷却液滴が多く存在することがある，雲中の過冷却液滴は，機体など に衝突すると凍結し，衝突面に氷層を形成する。これを着水現象と呼ぶ. 着水は，主翼においては翼性能の低下 やストール，エンジンにおいては作動効率低下の要因となるため，安全な航空機運航の妨げとなり，事実，着水 による航空機事故が世界各地で発生している（Isaac, et al., 2001）。この問題を解決するために，着水現象に関する 研究は, NASA をはじめとする世界的に主要な機関において，実験と数值解析の両方の側面から長く行われてい る (Wright, et al., 1997, Nilamdeen and Habashi, 2009, Presteau, et al., 2009, Veres, et al., 2011).

着水現象は，大気の温度やLWC（Liquid Water Content），液滴衝突面の壁面温度，液滴衝突の位置や質量などが 複雑に絡み合い発生する。また，衝突した液滴が瞬時に凍らずに表面を流れる現象（ランバック）は非常に重要 である。これらの発生条件を実験で設定するのは難しい。また，着水試験は膨大な費用を要し，試験装置の設置 場所も限られる. 従って, 本研究では近年のコンピュータの急速な発展もあることから, 数值流体力学 (Computational Fluid Dynamics, CFD）を用いて着水現象を解明する. CFDによる着水シミュレーションでは，着

\footnotetext{
No.14-00195 [DOI: 10.1299/transjsme.2014cm0209]

*1 東京理科大学大学院 工学研究科 機械工学専攻（干125-8585 東京都葛飾区新宿 6-3-1)

*2 正員, フェロー, 東京理科大学 工学部 機械工学科

E-mail of corresponding author: j4512703@ed.tus.ac.jp
} 
氷条件の設定も容易である. また, 雲中には多種の直径の液滴が存在するため, 平均液滴直径 (Median Volume Diameter, MVD）を定義して, 解析を行っている. 着水 CFD では, NACA 翼などを用いた二次元解析から, ジェ ットエンジン動静翼列における三次元解析まで, 幅広く, 着水現象の再現が可能である (Ozgen and Canibek, 2009, Hospers and Hoeijmakers, 2011, Aliaga, et al., 2011, Hayashi, et al., 2011).

主翼・尾翼の着水に関しては, 古くから研究されており, breed air や de-icer boots などをはじめとする防氷・除 水技術の対策も講じられている. しかし，エンジン着水において現状では，実用的な防水・除水装置は完備され ていない. ジェットエンジンの主な着水箇所は, スピナ, スプリッタ, ファン動翼, バイパス出口案内翼, 低圧 コンプレッサである. また, 近年では高圧コンプレッサなどのエンジンコアにおける着水発生事例もあり, エン ジン着水に対する研究が盛んに進められている（Jeanne, et al., 2006, Veillard and Habashi, 2011）.

着水現象に付随寸る現象に氷の離脱現象がある.ジェットエンジンの場合には, ファンに堆積した氷が成長し, 高速で回転しているファンの遠心力により翼表面から水が剥がれ落ちる. 離脱した水片はエンジンコアに吸い込 まれ, コアコンポーネントに損傷を与える. 本現象は, 大気中の水の密度, 水と壁面の付着力, 水と氷の接触力 など, 氷の物性值には不明な点が多く, 非常に複雑である. Papadakis ら（Papadakis, et al., 2007） は，水片を模擬 した長方形平板にかかる力とモーメント係数を風洞設備で測定し, 得られた空力データを用い主翼から飛散する 水片の追跡計算を行った．また，Baruzzi ら（Baruzzi, et al., 2007）は水片を模擬した立方体に対する流体構造連成 問題を解き, 飛散する水片の運動を解くことに成功した. しかし, 彼らの研究は離脱後の水片のみを対象にした ものであり, 水の成長や離脱の発生要因に関しては, 取り扱っていない. また, Brouwers ら (Brouwers, et al., 2010) は, ロータークラフトで発生する氷の離脱現象を調査するために, シミュレーションモデルを開発し，ホバリン

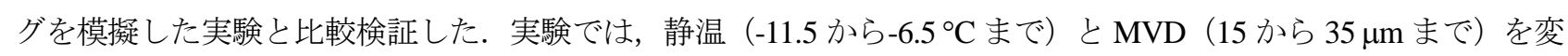
数に氷の離脱現象の発生が調査された. 彼らは温度が高くなりランバックが発生しチップ側の水層が厚くなると, チップ側において水の離脱現象が発生する知見を示した。しかし, 彼らの数值解析と実験值の間には, 水の離脱 が発生する時間と発生位置に大きく誤差を含むため, 水の離脱現象の再現性に劣る.

一方, 現存する着水モデルのほとんどは, 水の成長のみを再現するものであり水の離脱は考慮されておらず, 時間進行に伴い氷は成長し続ける. 従って, 本研究では, 過冷却液滴の衝突から, 水の成長, 水の離脱までを一 貫してシミュレーションできる新しい着水モデルを開発する. 本研究は, 水の離脱現象モデル開発のための基礎 研究であり, まずは氷に作用する遠心力と壁面付着力のみを考慮した簡単なモデルを用い, 水の離脱が再現でき るかということに重点を置く. 開発された氷の離脱現象モデルは, 過去に株式会社 IHI と北海道工業大学で実施 された, 氷の成長と離脱による流量変化の実験值と比較検証される. さらに, 氷の成長や離脱がファンの性能に 及ぼす影響についても同時に調査する. 本研究により, 遠心力と付着力のみの簡易的なモデルで水の離脱現象が 再現できること, 氷の成長と離脱が翼性能に及ぼす影響が示される.

\section{2. 数値計算手法}

\section{$2 \cdot 1$ 着永シミュレーションアルゴリズム}

本研究では, 以下の弱連成解析により氷の離脱現象をシミュレーションする.

(1) 計算格子を生成する

(2) 流れ場を計算する

（3）液滴軌道計算により，翼表面における液滴衝突特性を得る

（4）熱力学計算により，翼表面における着水量を得る

（5）水の成長に伴い, 水の離脱判定を行う

（6）水の離脱が発生したら，（2）に戻る

以下の節では, 各計算手法の詳細を示寸。

\section{$2 \cdot 2$ 流れ場計算}

流れ場は, 三次元圧縮性乱流場と仮定する. 支配方程式は, ファーブル平均を施した連続の式, ナビエ・スト ークス方程式, エネルギー式から成る. 空間離散化においては, 非粘性項には二次精度風上型 TVD スキーム (Yee, 
1987）を，粘性項には二次精度中心差分を，時間離散化においては，時間刻みの制約を緩和するため LU-ADI 法

(Fujii and Obayashi, 1986) を各々用いる. なお，乱流モデルには，Kato-Launder 修正を施した $k$ - $\varepsilon$ モ゙ル（Kato and Launder, 1993）を採用する.

\section{$2 \cdot 3$ 液滴軌道計算}

着水シミュレーションでは, 液滴の衝突位置が非常に重要となる. 従って, オイラー法と比較して計算コスト 面での不利は生じるが，液滴軌道計算はラグランジュ的に行う．液滴に作用する力は，抗力・遠心力・コリオリ 力とし, 重力は考慮しない. また, 液滴は完全な球形と仮定し, 衝突・変形・合体・分裂は無視し, 流れ場に影 響を及ぼさないとする（One-Way Coupling）。支配方程式には，以下の簡易化された Basset-Boussinesq-Oseen（BB-O）方程式を用いる.

$$
\frac{d \vec{U}_{w}}{d t}=\frac{3}{4} C_{D} \frac{\rho_{f}}{\rho_{w}} \frac{1}{d_{w}} \vec{U}_{r}\left|\vec{U}_{r}\right|-\left\{2 \vec{\Omega} \times \vec{U}_{w}-\vec{\Omega} \times\left(\vec{\Omega} \times \vec{r}_{w}\right)\right\}
$$

ここで， $U_{w}$ は液滴の速度， $U_{r}$ は気体と液滴の相対速度， $d_{w}$ は液滴直径， $\rho_{f}$ と $\rho_{w}$ は空気と水の密度である. 右辺 第二項は遠心力とコリオリ力を表し， $\Omega$ は回転速度， $r_{w}$ は液滴の半径位置である. $C_{D}$ は抗力係数であり，液滴の レイノルズ数 $\operatorname{Re}_{w}$ を用い，以下の式（Schiller and Naumann, 1935）のようになる.

$$
C_{D}=\frac{24}{\operatorname{Re}_{w}}\left(1+0.15 \operatorname{Re}_{w}^{0.687}\right)
$$

液滴の衝突特性に関しては, 以下のように求める。検査体積内に流入する液滴の質量流量 $Q_{i n}$ は,

$$
Q_{\text {in }}=A_{\text {in }} U_{\text {in }} L W C
$$

であり，ここで $A_{i n}$ は液滴の流入面積， $U_{i n}$ は液滴の流入速度である. 1 秒当たりに流入する液滴の個数 $N_{i n}$ は次 式のようになる.

$$
N_{i n}=\frac{Q_{i n}}{\rho_{w} V_{w}}
$$

ここで, $V_{w}$ は液滴の体積である. 以上より, 総液滴数に対する液滴の衝突率 $P_{i m}$ と単位時間・面積当たりの液滴 の局所的な衝突分布 $\beta$ が求まる.

$$
\begin{aligned}
& P_{i m}=\frac{N_{i m}}{N_{c o m}} \\
& \beta=P_{i m} \frac{N_{i n}}{A_{\text {cell }}}
\end{aligned}
$$

ここで， $N_{i m}$ は衝突液滴の個数， $N_{\text {com }}$ は計算液滴の個数， $A_{\text {cell }}$ はセル面積である. 


\section{$2 \cdot 4$ 熱力学計算}

熱力学計算には，Messinger モデル（Messinger, 1953）を用いる. 図 1 に本モデルのエネルギー収支の概略図を 示寸．本モデルは，検查体積内の質量バランスとエネルギバランスに基づき構成される.

$$
\begin{aligned}
& m_{i m}+m_{i n}=m_{a c}+m_{e s}+m_{\text {out }} \\
& Q_{i m}+Q_{i n}+Q_{a i r}+Q_{f r i}=Q_{a c}+Q_{e s}+Q_{o u t}+Q_{c o n}
\end{aligned}
$$

ここで, $m_{i m}, m_{i n}, m_{a c}, m_{e s}, m_{o u t}$ は，各々，壁面に衝突する液滴，隣のセルから流入する水，堆積する水，昇華・ 蒸発する水・水，隣のセルへ流出する水の質量である. $Q_{i m}, Q_{i n}, Q_{a i r}, Q_{f i r}, Q_{a c}, Q_{e s}, Q_{o u t}, Q_{c o n}$ は, 各々, 衝突 する液滴, 隣のセルから流入する水, 空力, 摩擦, 堆積する水, 昇華・蒸発する水・水, 隣のセル几流出する水, 対流のエネルギーである．式（7）（8）より，氷結率 $f$ を求め, ランバック質量および水堆積質量を得る.

$$
\begin{aligned}
& f=\frac{m_{a c}}{m_{\text {im }}+m_{\text {in }}} \\
& m_{\text {out }}=(1-f)\left(m_{\text {im }}+m_{\text {in }}\right)-m_{\text {es }}
\end{aligned}
$$

水結率とは, 水の凍結を表す指標であり，1 ならばセル内の水は全て凍結し，0 ならば凍らずに水の状態のまま隣 のセルに流れ込む.

\section{$2 \cdot 5$ 水の成長と離脱の再現手法}

着水シミュレーションでは，堆積した水が流れ場へ及ぼす影響を再現するために，着水による壁面形状の変化 を再現しなければならない，従来の再現手法では，水形状に沿って格子を再構成していた。 しかし，水形状が複 雑になれば, 格子再構成には経験とノウハウが要求され, 汎用性に欠ける. また, 本研究で扱う氷の離脱現象は, 水がある程度の大きさまで成長しなければ発生しないため, 従来の着水シミュレーションより大きい水を再現し なければならないことに加え，水が離脱した箇所では壁面形状の凹凸が生じるため，水形状は複雑さを増す，従 って, 本研究では従来の水表面に沿った格子の再構成は行わず，Icing Cell 法により水の成長と離脱による壁面形 状の変化を再現することにする. I cing Cell 法とは, 図 2 (b) に示すように, 計算セルを流体セルと着水セルに二 分寸る壁面形状再現手法である. 水が成長して水の体積が流体セルを満たせば，流体セルは着水セルとし，水が 離脱すれば，着水セルは流体セルに戻される，本手法では，着水し易い領域に予め，格子を密に設置しなければ ならないため，計算コストは増すが，面倒な格子の再構成を行う必要がなく，複雑な水形状にも対応できる．ま

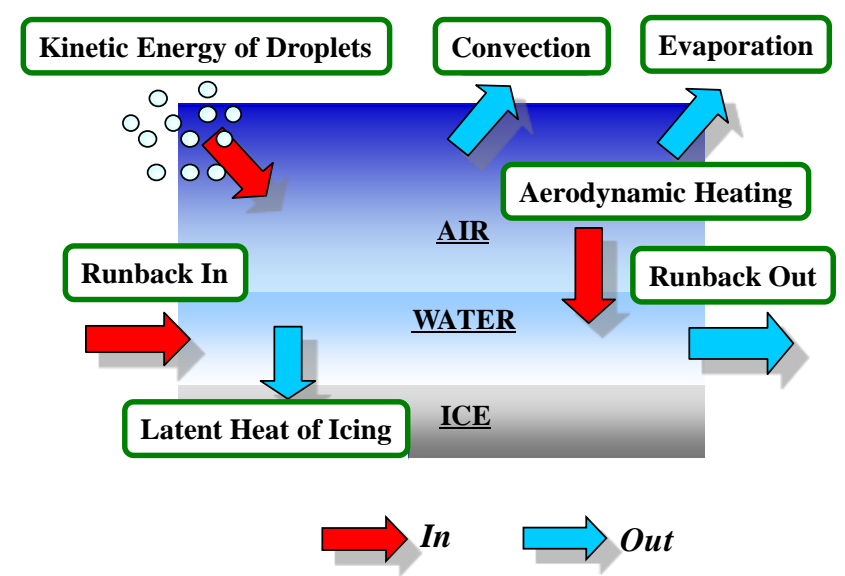

Fig. 1 Schematic Diagram of the Messinger Model 
た，格子再構成が不要になるため，着水シミュレーションアルゴリズムで示した流れ場計算から着水形状再現ま での一連の流れを自動化して，プログラミング可能である．従って，反復計算の点においても従来手法より有利 である.

\section{$2 \cdot 6$ 水の離脱判定}

エンジンファンでは, 水の成長とともに氷に作用する遠心力が大きくなり, 水と翼表面の付着力などの水に作 用する力を上回ったとき，水が離脱する．ファンに堆積した氷に作用する力として，翼表面と氷の界面における 付着力, 水間の接触力, 遠心力, 空気力などが挙げられるが, 空気力は, 接触力や遠心力と比べ 3 桁程オーダー が異なり微小であるため本研究では無視する. 従って, 水に作用する力は翼表面の付着力のみとし, 空気力の影 響と水中の破壊などは考慮しない，本研究では，この単純なモデルで水の離脱現象が再現できるかどうかも調査 する. 水に作用する翼表面付着力 $F_{a}$ と遠心力 $F_{c}$ は，以下の式のようになる.

$$
F_{a}=\tau A_{\text {cell }}
$$

$$
F_{c}=\rho_{i} A_{\text {cell }} B_{i} r \Omega^{2}
$$

ここで，ては単位面積当たりの付着力であり，水付着力試験（Murooka, et al., 2011）の值を採用する. $r$ は回転軸か らの距離， $B_{i}$ は水の厚さである. 各セルでこれらの力を見積り, 遠心力が付着力を上回れば, 水が離脱したと判 定し，着水セルを流体セルに戻す．Brouwers ら（Brouwers, et al., 2010）は，回転翼を用いて翼端付近から水が離 脱する傾向を実験的に示した。 この実験事実を参考にして, 本研究ではどこか 1 セルで水の離脱判定が下されれ ば，そのセルから翼端までの全てのセルにおいて，水が離脱したものと仮定する．水が離脱すると，再び，流れ 場計算・液滴軌道計算・熱力学計算を行う.

\section{NACA 翼における数値計算手法の検証}

\section{$3 \cdot 1$ 検証条件}

まず，実験データが豊富である NACA0012 翼を用いて，新しい壁面形状再現手法である Icing Cell 法の予測性 能を検証する. 本研究では, 着水箇所を正確に捉えるために, 着水し易い前縁周りに sub-grid を設置した重合格 子法を用いる．計算格子を図 3 に示す． I cing Cell 法は格子の埋め合わせにより着水形状を再現するため，従来の 格子を再構成する着水再現手法より解の格子依存性が強くなることが懸念される. 従って, 異なる格子解像度で

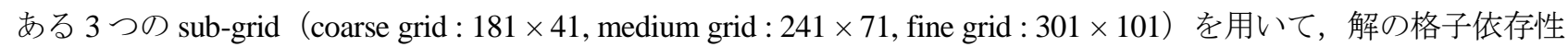

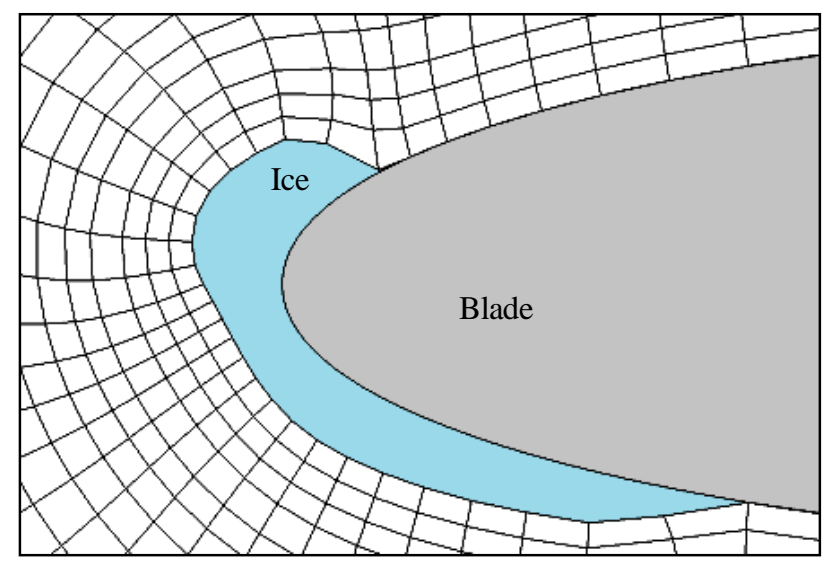

(a) Previous Method

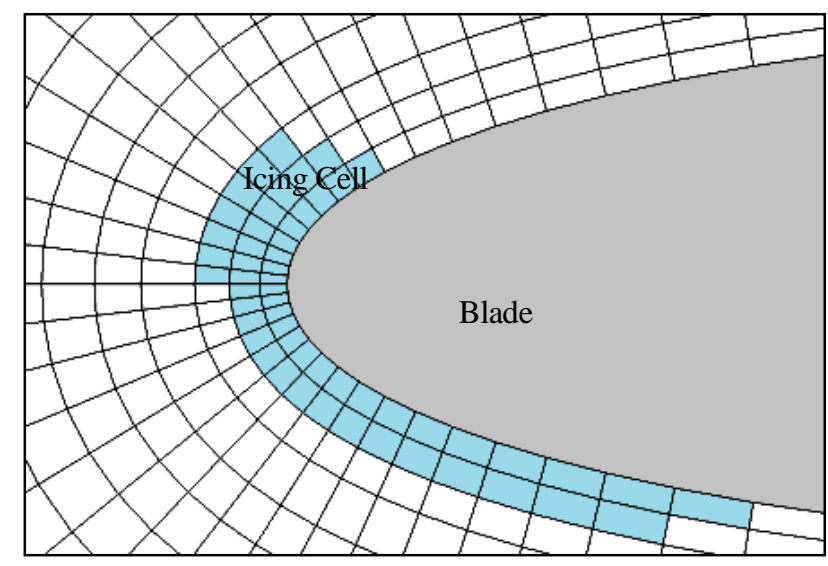

(b) Icing Cell Method

Fig. 2 Grid Systems for Reproducing the Ice Layer 
を検証する. main grid も含めた総格子点数は各々, 23,112 点, 32,802 点, 46,092 点であり, 計算領域は 20 chord 長四方と寸る．着水条件は，低い温度で発生する霧水であり，表 1 に計算条件を示す.

\section{$3 \cdot 2$ 検証結果}

本計算手法による計算值を，著者らのハウスコードで解析された従来手法による計算値，NASA の計算值と実 験值（Wright, et al., 1997）と比較することにより検証を行う. 図 4 に前縁付近の着水形状を示す.（a）は coarse grid，(b) は medium grid，(c) は fine grid を用いた結果である. 本計算手法によって得られた着水形状と着水領 域は共に, 他の計算值や実験值と比べ大差はない, また, 図 5 に各格子を用いて解析した翼周りの水層厚さ分布 を示す. グラフ中の横軸は前縁からの水平方向距離であり, 負の領域は正圧面側を正の領域は負圧面側を表す. 本グラフでは, coarse grid が他の格子と比較し, 正圧面側においては多少, 水層厚さを高く見積もっている傾向 がある.しかし, 全格子で共通して点を配置してある前縁 $x /$ Chord $=0$ の点で誤差を評価すると, coarse grid は fine grid に比べ $2.68 \%$ 水層厚さを大きく見積もっている程度である. 一般的に, 着水試験と数值解析では約 $30 \%$ の誤 差を含むとされているので, 数值解析上の格子解像度による $2.68 \%$ 誤差は許容範囲であると著者らは考える. 従って, 本検証では 3 種類の異なる解像度である sub-grid を用いたが, 得られた検証結果より解の格子依存性は 弱いとし，本研究で開発した Icing Cell 法による着水形状予測性能は妥当であると結論付けた.

\section{4. 数值計算条件}

\section{$4 \cdot 1$ 計算対象および計算格子}

本研究では，室岡ら（Murooka, et al., 2011）が行った軸流送風機の着水試験に従い，昭和電機製の軸流送風機： 快流シリーズ A2D6H-411 を対象とする. 図 6 に試験装置を示寸. 本軸流送風機は 12 枚の翼から構成されるが,

Table 1 Computational Conditions for Validation

\begin{tabular}{cl|c}
\hline \multicolumn{2}{c|}{ Airfoil Type } & NACA0012 \\
\hline Chord Length & {$[\mathrm{m}]$} & 0.53 \\
\hline Angle of Attack & {$[\mathrm{deg}]$.} & 4.0 \\
\hline MVD & {$[\mu \mathrm{m}]$} & 20 \\
\hline LWC & {$\left[\mathrm{g} / \mathrm{m}^{3}\right]$} & 1.30 \\
\hline Exposure Time & {$[\mathrm{s}]$} & 480 \\
\hline Free Stream Velocity & {$[\mathrm{m} / \mathrm{s}]$} & 58.1 \\
\hline Static Pressure & {$[\mathrm{kPa}]$} & 95.61 \\
\hline Static Temperature & {$\left[{ }^{\circ} \mathrm{C}\right]$} & -27.8 \\
\hline \multicolumn{2}{c}{}
\end{tabular}

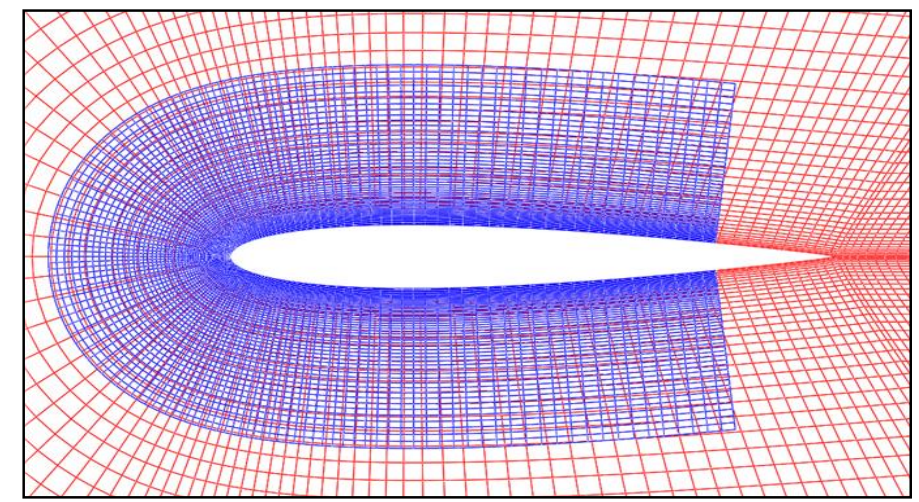

Fig. 3 Computational Grids used in the Validation (Red: Main Grid, Blue: Sub-grid)

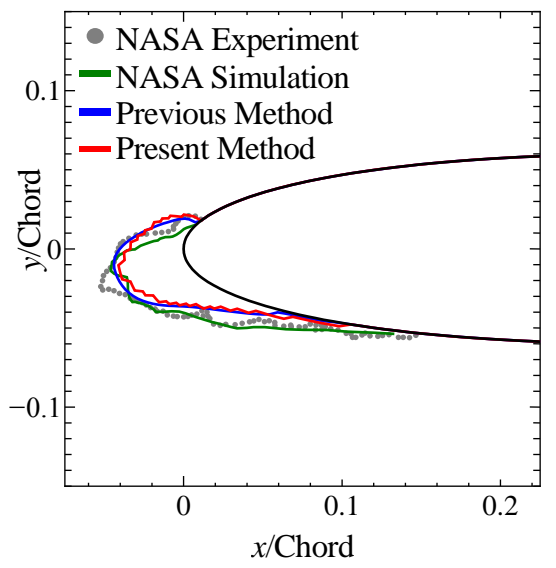

(a) Coarse Grid

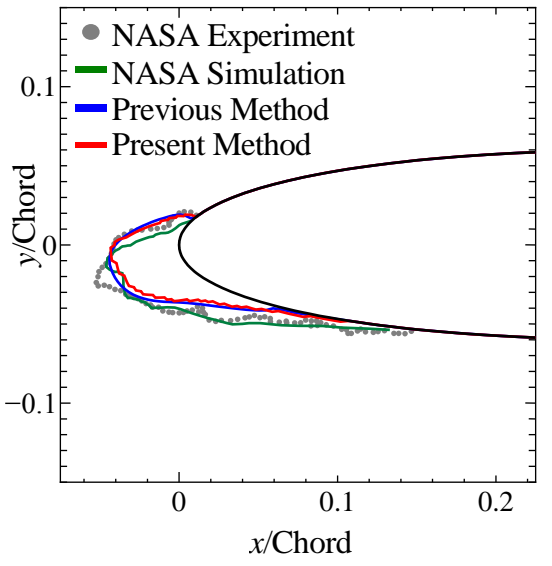

(b) Medium Grid

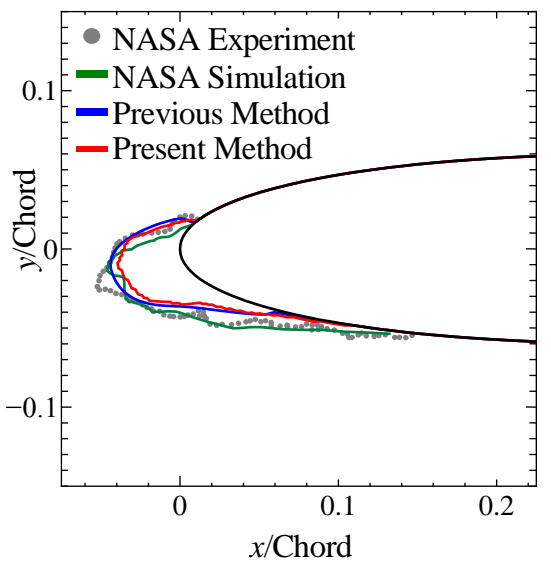

(c) Fine Grid

Fig. 4 Comparison of Icing Shapes used in the Validation 
周期性を考慮して翼 1 枚のみを計算対象とする．また，計算格子を図 7 に各々示す．本計算格子は，重合格子法 により生成される. sub-grid は, 前述したように着水セルの判定をするため, 着水し易い翼前縁付近で, 翼表面法 線方向の領域を広く，格子密度を密に設定する．また，正圧面側においては，水層は薄いが着水し易いため，同 じく格子密度は密とする．総格子点数は，6,272,284 点である.

\section{$4 \cdot 2$ 計算条件および境界条件}

計算条件を表 2 に示す. MVD $30 \mu \mathrm{m}$ の液滴を 1 個ずつランダムに流入境界から 500,000 個投入した後, 式 (3) -（6）を用いて局所的な液滴衝突特性を得る．流入境界では全温・全圧を固定，マッ八数を外挿とし，流出境界 では静圧固定，その他を外挿とする．壁面では，滑りなし・断熱・壁関数条件を課す．また，ピッチ方向は周期 境界条件とする. 解析時間に関しては，室岡らの試験では 480 秒間に渡り行われたが，本研究では遠心力と付着 力のみの単純なモデルで水の離脱現象が再現できるかということが重要であるため, 最初の離脱が発生するまで とする. さらに, 実験において着水し易い, 寸なわち, 水の離脱が生じ易い条件で行うために, 翼のスタガ一角 が設計点から 10 度ずらされた. 本研究も同条件で行うものとする.

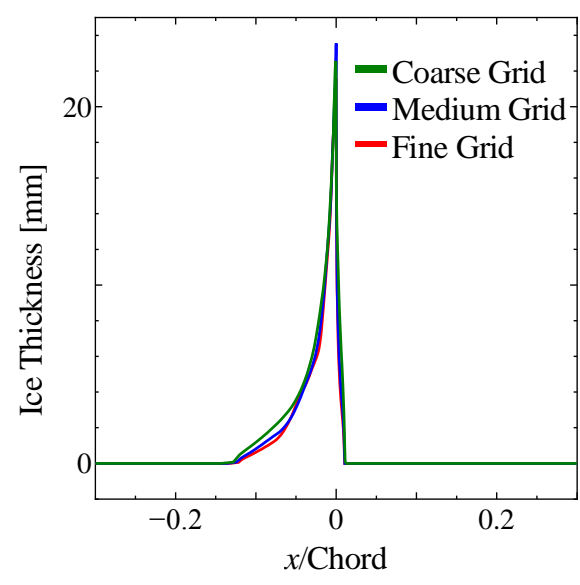

Fig. 5 Ice Thickness in Each Grid

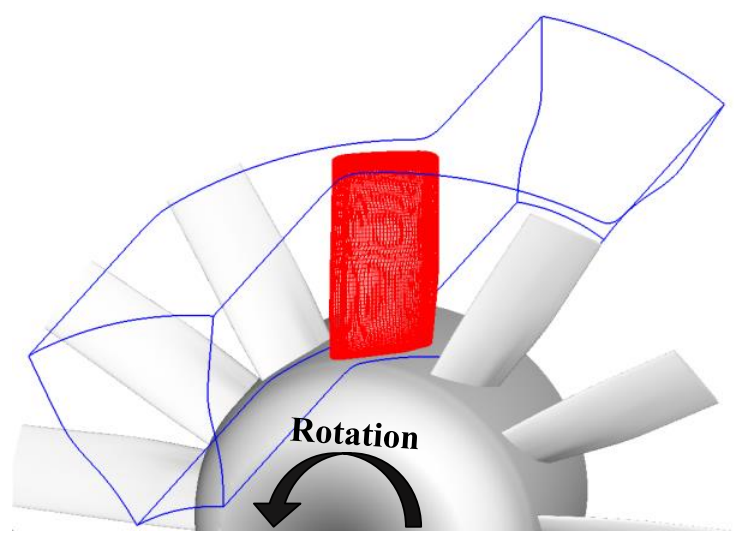

(a) Overview of the Computational Grid

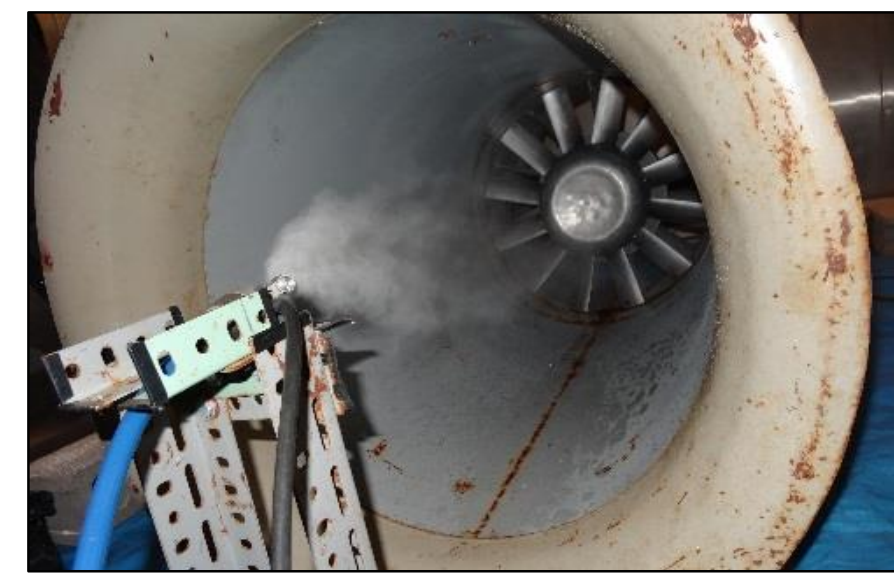

Fig. 6 Icing Test Device

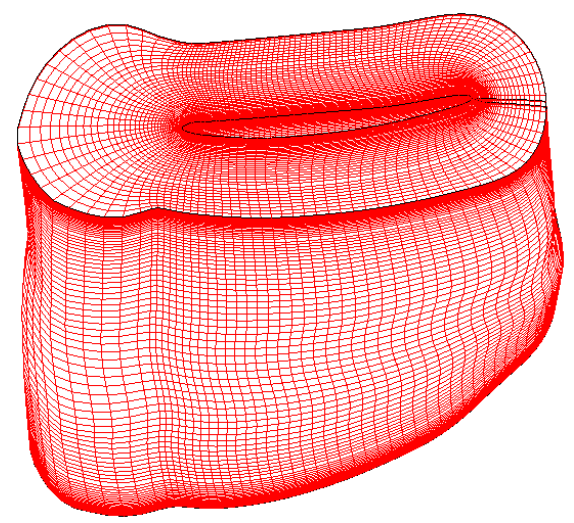

(b) Enlarged View of the Sub-grid (every 2 grid point)

Fig. 7 Computational Grids

Table 2 Computational Conditions

\begin{tabular}{cl|c}
\hline Rotating Speed & {$[\mathrm{rpm}]$} & 1,800 \\
\hline Initial Mass Flow Rate & {$[\mathrm{kg} / \mathrm{s}]$} & 5.21 \\
\hline Static Temperature & {$\left[{ }^{\circ} \mathrm{C}\right]$} & -5.0 \\
\hline LWC & {$\left[\mathrm{g} / \mathrm{m}^{3}\right]$} & 1.54 \\
\hline MVD & {$[\mu \mathrm{m}]$} & 30 \\
\hline
\end{tabular}




\section{$4 \cdot 3$ 流量の算出方法}

本研究では, 着水による流量低下と水の離脱による流量回復といった流量の時系列変化を, 室岡らの試験結果 と著者らの解析結果を比較する，従って，流量の算出方法が重要となるので，ここで双方の流量算出方法につい て説明しておく．室岡らの試験では，対象であるファンの軸中心から半径方向へ $10 \mathrm{~mm}$ 毎，計 32 点における流 速をピト一管により計測し，各々の点における流量を求め，その合計を測定流量としている．一方，著者らの数 值解析では，各々のセルにおける流速とセル面積を求め，その積分值を解析流量としている.

\section{5. 結果および考察}

\section{$5 \cdot 1$ 翼表面静温分布および液滴衝突質量分布}

翼表面における静温分布を図 8, 液滴衝突分布を図 9 に示寸. 着水シミュレーションは, これら 2 つのパラメ 一夕に大きく左右される．静温分布は，正圧面翼端付近を除いた領域では，水点以下となる．また，液滴は負圧 面にはほとんど衝突せず，正圧面に多く衝突し，特に，前縁に衝突が集中する．これらの領域は，静温も氷点以 下であるため，着水が発生し易い，着水解析值に関する詳細は，次節に示す．

\section{$5 \cdot 2$ 水の成長と離脱のシミュレーション}

図 10 に翼正圧面における水成長と離脱の時間履歴を示す. 前述したように, 水点以下であり液滴衝突量が多い 前縁に, 着水が集中的に生じる. その後, 着水した氷が成長し, 171 秒後に氷の離脱が確認される. 発生箇所は 図示した通り，遠心力が比較的大きく水層が厚い，約 $71 \%$ スパン位置の前縁である. 翼端側前縁から氷が剥がれ る傾向は, Brouwers らの実験（Brouwers, et al., 2010）と類似している. また，氷の成長と離脱による流量変化の 実験值との比較を図 11 に示す，図中の流量は，実験における着水前の流量を $100 \%$ とている．実験では，試験 開始から 179 秒後に流量が回復し始めたことから，氷が離脱した時間は 179 秒であったと考えられる. 本研究に おける水の離脱現象の発生時間は 171 秒であり, 概ね一致している. 従って, 本研究で開発した氷の離脱現象モ デルは，氷の離脱発生時間については，妥当な予測性能を有することがわかる.

\section{$5 \cdot 3$ 水の成長と離脱によるファン性能の変化}

本節では, 水の成長や離脱が流れ場へ及ぼす影響について述べる. まず, 図 10 で示した氷の成長と離脱による 流量の時系列值に関してだが，本研究では，実験のような水の離脱後の著しい流量回復が確認されていない. 実 験では, 最初の水の離脱の発生直前における着水による流量低下は $27.6 \%$, 発生直後における水の離脱による流

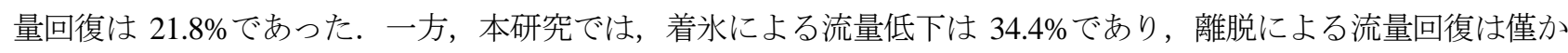
10.6\%である. 着水による流量低下の誤差に関しては，着水計算を 171 秒という長時間に渡り行ったことが原因 である. 着水シミュレーションでは, 着水が流れ場計算や液滴軌道計算に及ぼす影響を正確に再現するためには, 着水時間を数回に分割し，繰り返し計算を行わなければならない. 例えば， 3 章において着水モデルの検証に用 いた NACA 翼の二次元解析では, 480 秒の計算時間を 120 秒毎に分割し，2・1 節で示した繰り返し計算を 4 回行

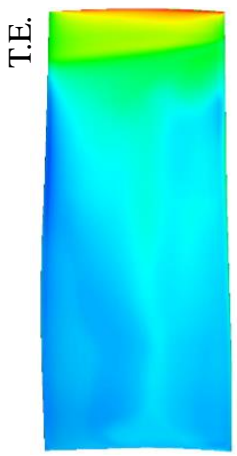

(a) Pressure Side

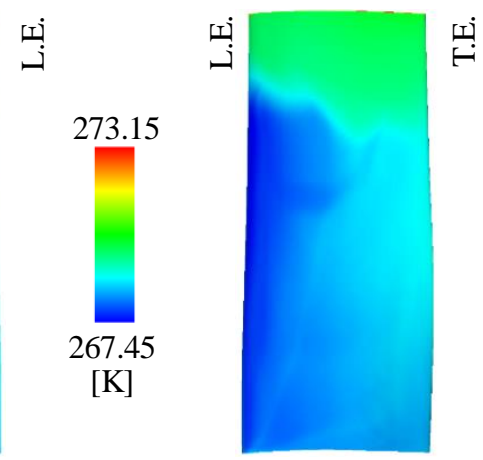

(b) Suction Side

Fig. 8 Static Temperature

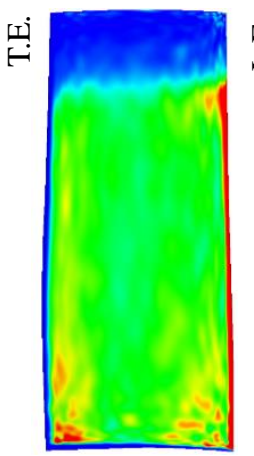

(a) Pressure Side

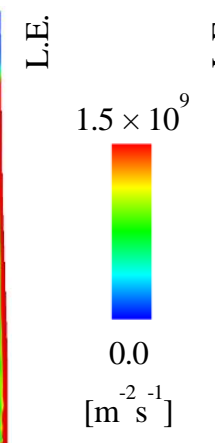

Fig. 9 Local Water Distribution 
っている．筆者らの経験では，二次元 NACA 翼の解析の場合， 120 秒以下に分割して解析を行えば，解が着水分 割時間に依存しないことがわかっている，従って，流れ場計算・液滴軌道計算・熱力学計算・着水セル判定とい うサイクルを 100 秒程度毎に分割して解析すれば，予測性能をさらに高めることが期待できる．しかし，検証用 の二次元解析ではこの手法で問題はないが，三次元解析になれば，これには膨大な計算コストを要すること，前 述したように着水試験は約 30\%の誤差を含むことから, 本シミュレーションにおける着水による流量低下の 9.39\%の実験值との誤差は, 問題にならないと考える. 一方, 水の離脱による流量回復には大きい誤差を含んでい る. この誤差要因は, 離脱する氷の体積の不一致による. 実験では, 初期流量の $94.3 \%$ ま゙水の離脱発生後の流 量が回復していることから，かなり大きい水片が翼から剥がれ落ちたことが予測される．本研究で開発した氷の 離脱現象モデルには, 氷と氷の間で作用寸る接触力が考慮されていない. 実現象では, 遠心力が大きくなった箇 所で発生する水の離脱現象に加え, 壁面に付着した氷が離脱しょうとする水との接触力により引っ張られること により, 離脱するといった現象が考えられる. これらの水に関しては, 遠心力と付着力のみを考慮した本モデル

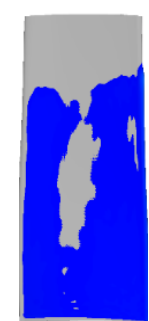

(a) $10 \mathrm{~s}$

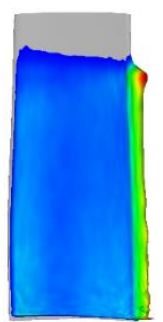

(j) $100 \mathrm{~s}$

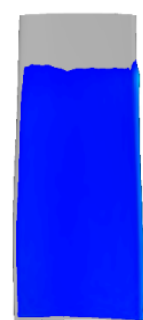

(b) $20 \mathrm{~s}$

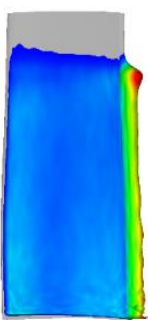

(k) $110 \mathrm{~s}$

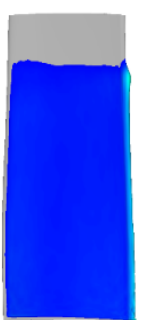

(c) $30 \mathrm{~s}$

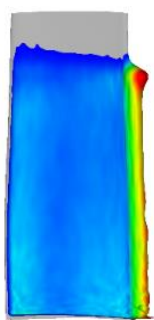

(l) $120 \mathrm{~s}$

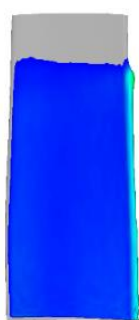

(d) $40 \mathrm{~s}$

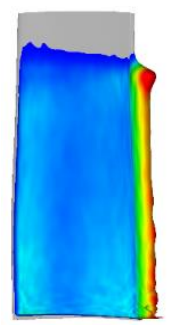

(m) $130 \mathrm{~s}$

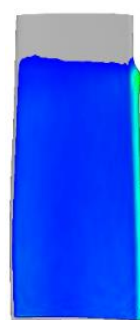

(e) $50 \mathrm{~s}$

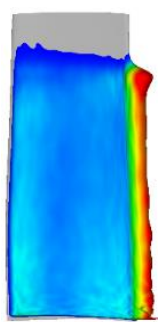

(n) $140 \mathrm{~s}$

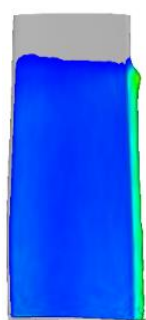

(f) $60 \mathrm{~s}$

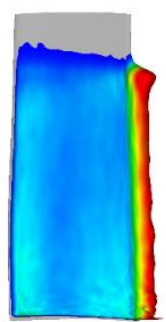

(o) $150 \mathrm{~s}$

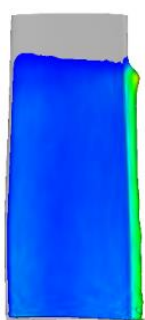

(g) $70 \mathrm{~s}$

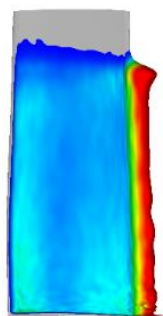

(p) $160 \mathrm{~s}$

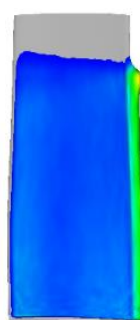

(h) $80 \mathrm{~s}$

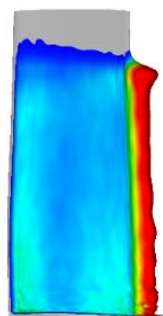

(r) $170 \mathrm{~s}$

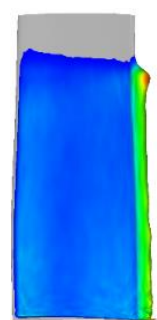

(i) $90 \mathrm{~s}$

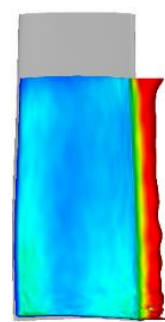

(s) $171 \mathrm{~s}$

Fig. 10 Temporal Evolution of the Ice Layer on the Pressure Side

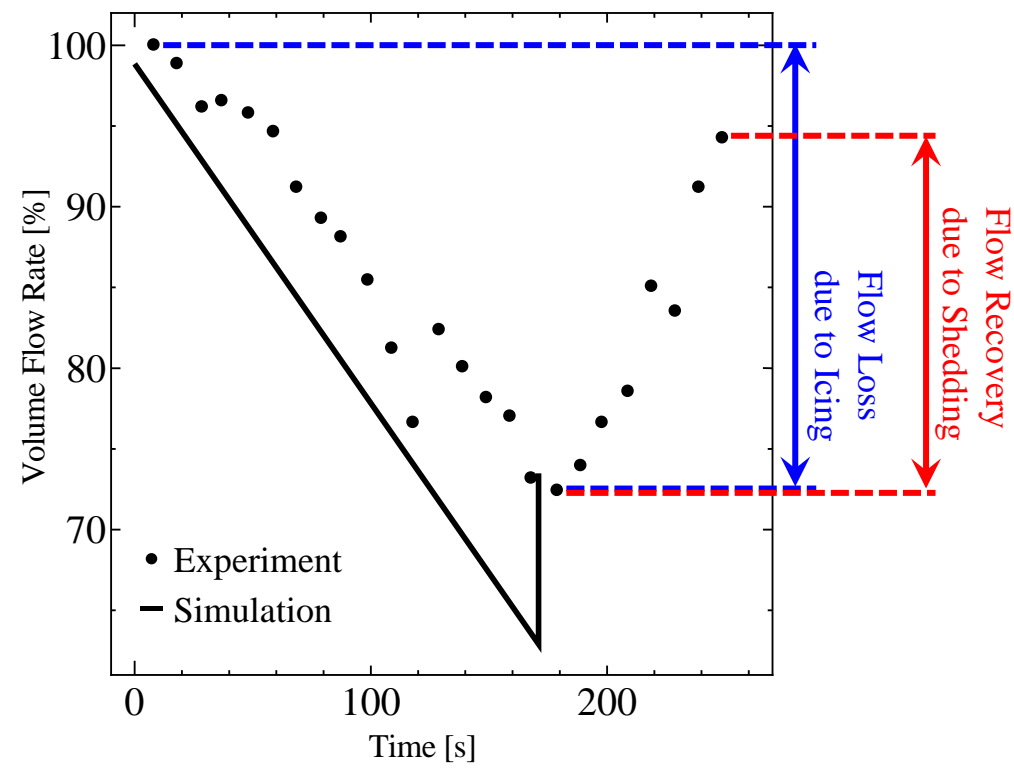

Fig. 11 Temporal Change of Volume Flow Rate 
では再現できないため，離脱する水の体積を過少評価していることが懸念される．さらに，実験では最初に氷が 離脱した後も氷の成長と離脱を繰り返し，179-249 秒間において徐々に流量が回復している.この時間における 水の成長による流量低下が実験で確認されないのは, 離脱する氷の体積が新たに成長する水の体積を上回るから だろう. 本研究では, 最初の 1 回目の氷の離脱現象が発生する時間までしか, シミュレーションを行っていない. つまり, 数回の離脱現象が発生する時間までシミュレーションを行い, 八ブ側の氷が成長し遠心力が高くなり, ハブ側において離脱が発生すれば，さらなる流量の回復が期待できる.

図 12 は，氷の離脱断面付近における速度ベクトルである.（a）は離脱前，(b) は離脱後を各々表す. 水の離脱 前は, 堆積した水がブロッケージになり, 翼負圧面側における着水箇所周りの流れが減速している. しかし, 水 が離脱すると, 翼負圧面側における流れの加速や, 加速領域の拡大が確認できる. このような離脱面付近の負圧 面側における加速領域により, 図 10 で示した氷の離脱後の流量回復が引き起こされたと考えられる.

最後に, 氷の成長や離脱がもたら寸翼性能の変化について述べる. 図 13 は, ファン後縁近傍における全圧分布 の軸断面図であり，(a) は着水前，(b) 水の離脱直前，(c) は離脱直後を各々表す. まず, 着水前に関してだが, 50-70\%スパン位置において高圧領域が形成されているが，70\%スパン以降においては，ケーシング壁面を除いて 高圧領域が形成されていない. これは，70\%スパン位置以降では，翼前縁から大きく剥離しているからである. また, 水の離脱直前に関しては, 着水により流量が低下したため, 着水前のような顕著な高圧領域は確認されな い. 本シミュレーションでは, 前縁に大きい水が付着しているため, 翼後縁の低圧領域も翼端方向へ拡大してい る. さらに, 水の離脱直後に関しては, 前述したように $71 \%$ スパン位置で離脱が発生したことにより，ミッドス パン付近において着氷前ほどではないが, 高圧領域が形成されている. これは, 図 12 で示した氷の離脱発生箇所 において流れが加速したことによる流量回復に起因するものと考えられる.つまり，氷の成長によりファンの性 能は低下するが，成長した氷が離脱すれば性能は回復する.

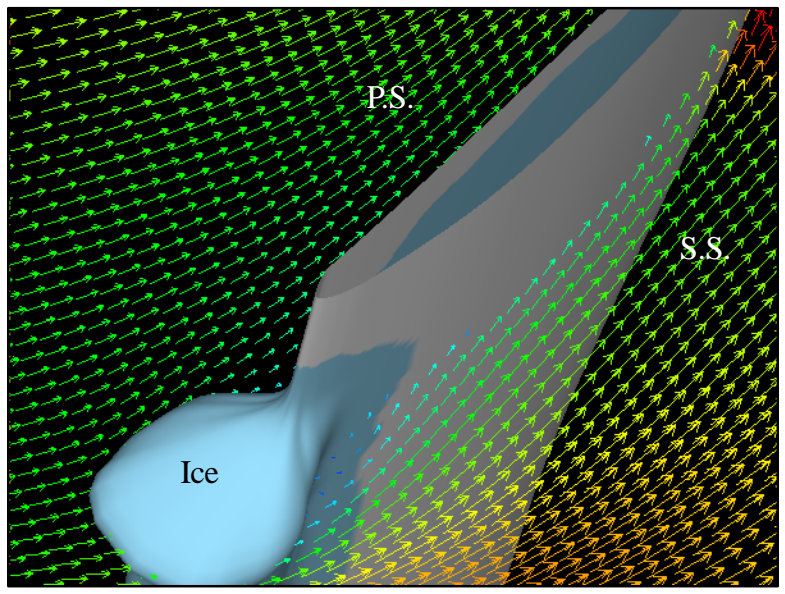

(a) Before Shedding

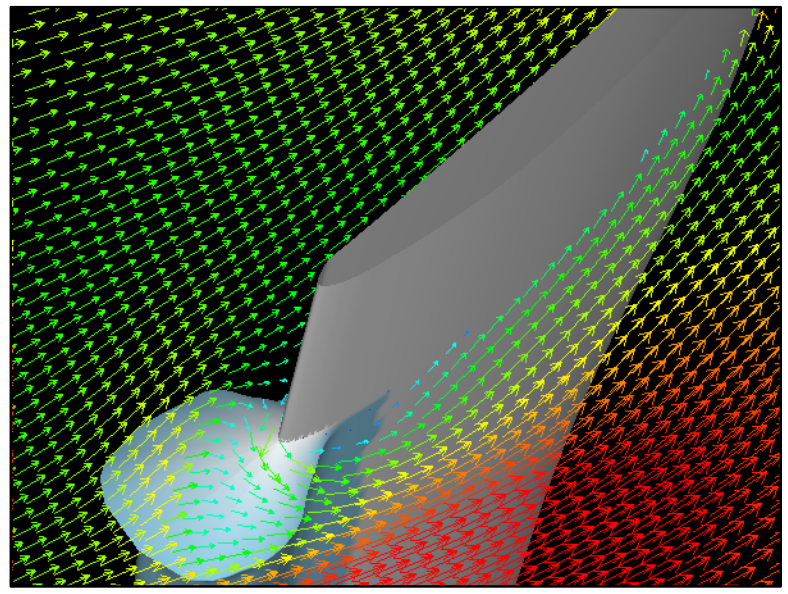

(b) After Shedding

Fig. 12 Velocity Vector at Shedding Span Section

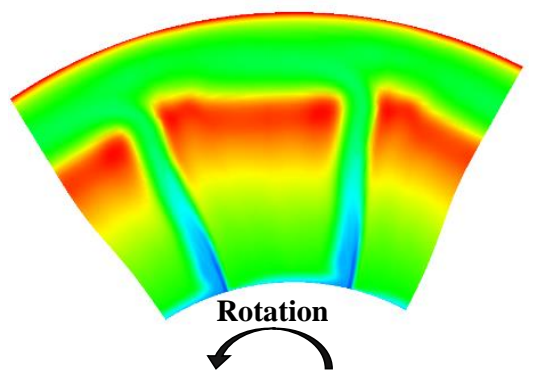

(a) Clean

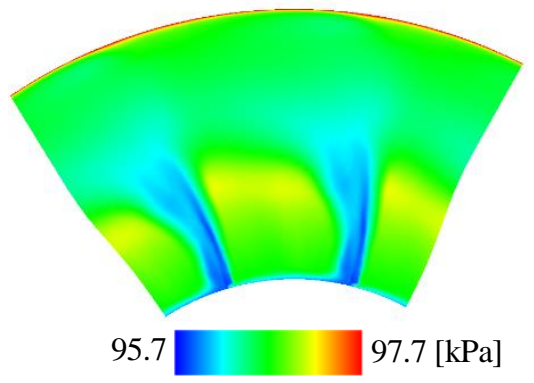

(b) Before Shedding

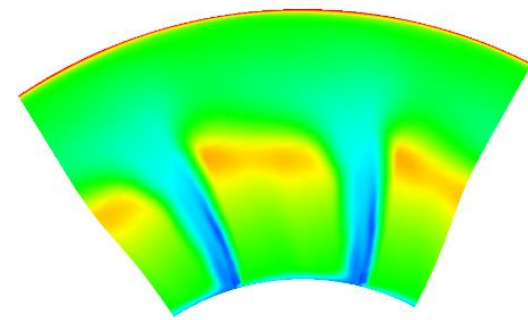

(c) After Shedding

Fig. 13 Total Pressure at Axial Section behind Trailing Edge 
氷の離脱現象はファンにのみ着目寸れば，離脱前より性能が向上するため，好都合である．しかし，エンジン 全体で考えると, 離脱した水片がエンジンコアに与える負の因子は, 氷が成長するほど大きい. 着氷させないこ とが最善ではあるが，現在の技術では，航行中のエンジン着水は避けられない，以上より，ジェットエンジンに 対して, 水が大きく成長しないうちに, 水を離脱させることが可能な新しい防水技術の開発を提案する必要があ ると言える. そのためには, 氷の離脱現象発生要因の解明が必要である. 今後, 雪水分野の研究者と連携し, 水 と水の接触力や水の密度・硬さなど未解明であり，モデル化が難しい水の物性値に関する知見が必要であると感 じざるを得ない.

\section{6. 結 言}

氷の離脱現象モデルを開発し, 水の成長と離脱による流量変化の実験值との比較検証, 水の成長と離脱がファ ンの性能に及ぼす影響調查を行った。本研究により得られた知見を以下に示す.

・ 本研究で開発した水の離脱現象モデルは，氷が離脱する時間においては，妥当な予測性能を有する

・ 本研究で開発した氷の離脱現象モデルは, 水が離脱する体積に誤差を含み, 離脱による著しい流量回復が再 現できない

・ 本研究では, 氷が離脱すると着水により阻害されていた離脱現象発生箇所の流速が回復する

・ 本研究では, 水が成長するとファン性能は低下寸るが離脱すると性能が回復するため, ファンのみに着目す れば，水の離脱現象は良い働きをする

今後の課題として, 水が離脱する体積を正確に再現できるように本モデルを改良しなければならない，また，本 計算手法は計算コストが大きいため, 数回の離脱現象に対応できる計算手法の開発が必要である. 最終的には, 離脱した氷片の軌道計算の追加, ジェットエンジン動静翼列への適用などを計画している.

\section{謝 辞}

本研究で参考にした氷の付着力と氷の成長と離脱による流量変化の実験值は, 株式会社 IHI の室岡氏, 实戸氏, 北海道工業大学の平元准教授, 箕谷氏が行った氷の付着力試験によって得られたものである. また, 日本学術振 興会による科研費（認可番号 25286101）の助成を受けている.ここに，深く感謝の意を称する.

\section{References}

Aliaga, C. N., Aubé, M. S., Baruzzi, G. S. and Habashi, W. G., FENSAP-ICE-Unsteady: unified in-flight icing simulation methodology for aircraft, rotorcraft, and jet engines, Journal of the Aircraft, Vol. 48, No. 1 (2011), pp. 119-126.

Baruzzi, G., Lagace, P., Aube, M. and Habashi, W., G., Development of a shed-ice trajectory simulation in FENSAP-ICE, Proceeding of the SAE Aircraft and Engine Icing International Conference (2007).

Brouwers, E. W., Palacios, J. L., Smith, E. C. and Peterson, A. A., The experimental investigation of a rotor hover icing model with shedding, Proceeding of the American Helicopter Society 66th Annual Forum (2010).

Fujii, K. and Obayashi, S., Practical application of improved LU-ADI scheme for the three-dimensional Navier-Stokes computations of transonic viscous flows, AIAA Paper, 86-0513 (1986).

Hayashi, R., Kawakami, K., Suzuki, M., Yamamoto, M., Shishido, S., Murooka, T. and Miyagawa, H., Numerical simulation of icing phenomena in fan rotor/stator interaction field, Proceedings of the 10th International Gas Turbine Congress (2011), pp. 1-5.

Hospers, J. and Hoeijmakers, H., Numerical simulation of SLD ice accretions, SAE Technical Paper, 2011-38-0071 (2011).

Isaac, G. A., Cober, S. G., Strapp J. W., Korolev, A.V., Tremblay, A. and Marcotte, D. L., Recent Canadian research in aircraft in-flight icing, Journal of the Canadian Aeronautics and Space, Vol. 47, No. 3 (2001).

Jeanne, G., Mason, J., Strap, W. and Chow, P., The ice particle threat to engines in flight, Proceeding of the 44th AIAA Aerospace Sciences Meeting and Exhibit (2006).

Kato, M. and Launder, B. E., The modeling of turbulent flow around stationary and vibrating square cylinder, Proceedings of the 8th Symposium on Turbulent Shear Flows, 10-4-1-10-4-6 (1993).

Messinger, B. L., Equilibrium temperature of an unheated icing surface as a function of airspeed, Journal of the Aeronautical 
Sciences, Vol. 20, No. 1 (1953), pp. 29-42.

Murooka, T., Shishido, S., Hiramoto, R. and Minoya, T., Surface coating effect on protection of icing for axial fan Blade, Proceedings of the SAE International Conference on Aircraft and Engine Icing (2011).

Nilamdeen, S. and Habashi, W. G., FENSAP-ICE: modeling of water droplets and ice crystals, Proceedings of the 1st AIAA Atmospheric and Space Environments Conference (2009).

Ozgen, S. and Canıbek, M., Ice accretion simulation on multi-element airfoils using extended Messinger model, Journal of the Heat and Mass Transfer, Vol. 45 (2009), pp. 305-322.

Papadakis, M., Yeong, H. and Suares, I. G., Simulation of ice shedding from a business jet aircraft, Proceedings of the 45th AIAA Aerospace Sciences Meeting and Exhibit (2007).

Presteau, X., Montreuil, E., Chazottes, A. and Vancassel, X., Experimental and numerical study of scallop ice on swept cylinder, Proceedings of the 1st AIAA Atmospheric and Space Environments Conference (2009).

Schiller, L. and Naumann, A., A drag coefficient correlation, Z. Ver. Deutsch, 77 (1935), pp. 318-320.

Veillard, X. and Habashi, W. G., Icing simulation in multistage jet engine, Journal of the Propulsion and Power, Vol. 27, No. 6 (2011).

Veres, J. P., Jorgenson, P. C. E. and Wright, W. B., Modeling the effects of ice accretion on the low-pressure compressor and the overall turbofan engine system performance, NASA TM-2013-217034 (2011).

Wright, W. B., Gent, R. W. and Guffond, D., DRA/NASA/ONERA collaboration on icing research, NASA CR-202349 (1997).

Yee, H. C., Upwind and symmetric shock-capturing schemes, NASA-TM-89464 (1987). 